\title{
Measuring the Proportion of the Defendant's Retaliatory Act in Self-Defence under Nigerian Law
}

\author{
Dr Emmanuel OC Obidimma ${ }^{1}$, Dr Angela EObidimma ${ }^{2}$ \\ Department of Commercial and Property Law, Faculty of Law, NnamdiAzikiwe University, PMB 5025, Awka, \\ Anambra State, Nigeria. \\ Department of International Law and Jurisprudence, Faculty of Law, NnamdiAzikiwe University, PMB 5025, \\ Awka, Anambra State,Nigeria.
}

\begin{abstract}
The defence of self-defence as provided in the Nigerian penal statutes is in consonance with the constitutional protection guaranteed every Nigerian to use reasonable and necessary force for the defence of person and property, from unlawful violence. The defence, where successfully pleaded, completely exculpates a defendant from criminal liability. The important condition for the application of this defence is that the person assailed must be reasonably apprehensive of death or bodily harm and at the time, he uses any force as is necessary even if that results in the death of the assailant. However, in evaluating thedefence, the courts most often than not, read into the law what is not in the letter of the law and thereby hold the view that the retaliatory force used must be commensurate or proportionate with the attack received. This paper analyses this issue and holds the view that there is no provision in the law requiring that the defendant's act must be proportionate to the attack received. It is also the view of this paper that once there are reasonable grounds for the defendant's belief that he was in imminent danger, the amount of force used by him to preserve his life becomes immaterial. The paper recommends that trial courts should apply the letter and spirit of the law as enacted by the legislature in order to avoid miscarriage of justice.
\end{abstract}

Keywords: Self-defence, Retaliatory Act,Proportion, Apprehension of death, Nigerian Law

\section{Introduction}

Given the nature of man, the right to defend oneself is inherent, instinctive and inalienable. That is to say that self-defence is part of human nature. It is a right which enures to a person because he/she is human. Indeed, it is viewed as a fundamental right. To this end, (Article 12 of the Universal Declaration of Human Rights, 1948) encapsulates this view. It states that:

No one shall be subjected to arbitrary interference with his privacy, family, home or correspondence, nor to attacks on his honour and reputation. Everyone has the right to the protection of the law against such interference or attacks

(Underling ours for emphasis)

As a concept in criminal law, self-defence is dynamic, varying from country to country and from time to time depending on the circumstances of each case. (Yadav, 1993) But it is important to note that self-defence has not always been legally recognized as a defence to a criminal act. Before 1267, a man was hanged in cases where self-defence would have exculpated him were it done today. At that time, he was treated as if he had acted feloniously because such killing that resulted from his defending himself was not justifiable homicide. Such a person was not entitled to an acquittal (Yadav, 1993). But with the coming into existence of the welfare states, the responsibility of protecting the dignity of the person and property of individuals was taken over by the state. The judicial arm of the state recognized the legitimate right of the individual to self-defence which the legislature signaled its approval by providing and enumerating its ingredients in the penal statutes.

It has been posited that the concept of self-defence as a legitimate legal term originated from the Roman law principle of dominium pursuant to which any attack on the members of the family or any property belonging to it was regarded as a personal attack on the pater familias. (Frier and McGinn, 2004). This was possible because as was effectively argued by Hobbes (1909), although some may be stronger or more intelligent than others in their natural state, none are so strong as to be beyond a fear of violent death, which justifies self-defence as the highest necessity.

Historically, self-defence has also been said to derive from Article 6 of the French Penal Code, 1791 which made a provision to the effect that "manslaughter is legitimate if it is indispensably dictated by the present necessity of legitimate defence of oneself or others" (Ewulum and Agwuncha, 2013). This is how the concept of self-defencecrept into the Constitution of most nations of the world. It has become the foundation of the defence in the face of attacks on the person or property of others where the attacked person holds a 
reasonable apprehension of imminent danger of death or grevious bodily harm. This article examines and analyses the defence of self-defence under Nigerian law with a view to highlighting the essential condition for its successful plea. The examination begins with the meaning of the defence, incidence of the defence, the defence under Nigerian law in the course of which the ingredients of the offence is also discussed. The paper then discusses the futility of measuring the proportionateness of the retaliatory act of the defendant. The conclusion that is reached is that the attempt to measure the proportionateness of the force used by the defendant amounts to reading into the law what the legislature has not enacted. The paper then recommends that trial courts should endeavour to apply the letter and spirit of the law and not read into it, what is not there in order to avoid miscarriage of justice.

\section{The Meaning of Self-Defence}

The term 'self-defence' is derived from the latin term "se defendendo", which means defending oneself, in self-defence. In that sense, homicide committed se defendendo is excusable (Yadav 19993). It is the use of force to protect oneself, one's family or one's property from real or threatened attack for a person is justified in using a reasonable amount of force in self-defence if he or she believes that the danger of bodily harm is imminent and that force is necessary to avoid this danger (Garner 2004). As Ashworth (1991) put it, "The law of self-defence, as it is applied by the courts, turns on two requirements: the force must have been necessary, and it must have been reasonable".

This defence is not confined to a person's defence of his own life alone. It extends to the defence of rape and other assaults and the defence of other persons to whom one stands in certain defined relations (Walker 1980). In this regard, Saunders (1970) has defined self-defence as:

The defence of one's self, or the mutual and reciprocal defence of such as stand in the relations of husband and wife, parent and child, master and servant. In these cases, if the party himself or any of his relation is forcibly attacked in his person or property, it is lawful for him to repel force by force; and the breach of the peace which happens is chargeable upon him only who began the affray.

This definition illustrates the historical development of the defence. This is so because originally, selfdefence was for the protection of one's own person against some injury caused or threatened by another. In course of time, it was extended to the protection of one's property within its ambit. Subsequently, the defence was extended to the safety of one's habitation and other members of his family (Yadav, 19993)

The defence of self-defence then means the right of a man to repel force by force, even to that of taking of life in self-defence of his person, property or habitation, or of a member of his family against anyone who manifests, intends, attempts or endeavours by violence or surprise, to commit a forcible felony. The defence essentially is one based on the concept of self-preservation, which is the natural instinct in every living creature, to be alive and survive every possible adversity. Under the law of nature, killing done to prevent violent or atrocious crimes such as rape, murder, armed robbery, arson etc, is justifiable. Thus, the necessity of self preservation is the mother of self-defence. It is an action taken by a person, out of necessity, where a man finds himself in a position of imminent peril, either to himself or another and it becomes necessary to strike the assailant even up to death, to save his life or that of another, or to save property from a serious harm. Any action taken by such a person in the circumstance is legally justified.

Under Nigerian law as has been expressed in a long line of judicial decisions, the purport of selfdefence is to negative the existence of an offence so that when a person kills another in self-defence, the killing does not amount to an offence but leads to a total exoneration of the defendant. This was the opinion of the court in Jeremiah v. State (2012)14 NWLR (Pt. 1320) 248. It is a legitimate defence which completely exonerates a person who uses force to defend himself or another person or property even if such use of force results in the death of the assailant. In the case of Nkpuma v. State (1993)9 NWLR (Pt. 317)374, it was held that where an unprovoked assault causes the victim reasonableapprehension of death or grievous harm, he is entitled to use such force to defend himself as he believes on reasonable grounds, to be necessary topreserve himself from the danger and this he is entitled to do even though such forcemay cause death or grievous harm. This is the crux of the defence of self-defence.

\section{Incidence of Self-Defence}

To buttress the point of this paper even more, it is pertinent to look at some instances in which it is almost impossible, to the point of nonsense, for a defendant to measure the proportion of force he needs to use in fending off an unprovoked attack. The following examples will suffice:

Basil Parasiris was a 41-year -old businessman who lived with his wife and two children in the south shore region of Montreal. In the early morning hours of March 2, 2007, the Parasiris family was awakened by a surprise visit from nine police officers from the suburb of Laval. The police suspected Parasiris of drug trafficking and had a warrant to search his home. In order to prevent Parasiris from being able to destroy potential evidence, this warrant allowed the cops to use "dynamic entry" to enter the home without knocking. 
They entered Parasiris's bedroom with their guns drawn, but Parasiris grabbed his .357 Magnum and fired at them. Constable Daniel Tessier was shot twice and killed instantly while Parasiris's wife and another officer were wounded in the ensuing gunfire. When Parasiris realized the intruders were police officers, he immediately dropped his weapon. Parasiris was charged with first-degree murder, but he maintained that he only acted in self-defence to protect his family. Since the police officers were in plain clothes and did not identify themselves, Parasiris assumed it was a robbery attempt. Even though Parasiris admitted to being involved with drug trafficking years beforehand and there was a small amount of cocaine found in his house, there was nowhere near enough evidence to justify the use of "dynamic entry" search warrant. A judge determined that the warrant was illegal and would be inadmissible in court. In June 2008, Parasiris was put on trial and acquitted of the shooting of Constable Tessier. He acted in self-defence, to protect his family. He did eventually receive a 20month sentence for storing illegal firearms in his home, but was paroled after only serving five months. (Warder, 2014) Could Basil Parasiris have been able to gauge the quantum of force used by the cops in their "dynamic entry" into his residence to be able to apply the appropriate force in defending himself and family in the circumstances of this story?

Similarly, when a gang of robbers stormed the home of a middle-aged woman identified as Adenike, armed with cutlasses, knives and iron rods, they never knew they would meet their match in the woman as one of them was overpowered by the lady who collected his weapon and stabled him to death. The woman who was recuperating from the injuries she got in the scuffle with the hoodlums in a hospital in Lagos, narrated how the miscreants stormed her apartment at about $2 \mathrm{a} . \mathrm{m}$. and ordered her to hand over her valuables and cash or they would kill her.It was learnt that when the robbers got to Adenike's apartment, there was a struggle during which one of the robbers, identified as Qaudri Iginla, cut her with a knife. Adenike was said to have wrenched the knife from Iginla, and stabbed him in the stomach. The robbery suspect reportedly lost balance and fell off from the two-storey building. Neigbours, who learnt of the robbery were said to have alerted the police from the Adeniji Adele Division of the Nigeria Police. The other suspected robbers reportedly escaped after the police got to the area. The policemen were said to have rushed Iginla, who was unconscious, to the Lagos Island General Hospitalwhere he later died, while Adenike was also taken by her family to a private hospital. (Dachen, 2015) Again, could Adenike have determined the proportion of force used by the career criminals in order to determine the quantum of force to use in defending herself in the circumstance?

Another example: a young chef,Shyan Ricky Hill was going home from work late at night on a Christchurch bus. He was by himself and minding his own business. A group of young thugs started harassing him because he happens to be wearing a red sweatshirt-and red, in this pathetic aping of Los Angeles street culture, was the colour of a rival gang. He was spat on and a cigarette lighter was thrown at him. The bus security video reportedly shows him cowering and frightened. As the bullies left the bus, the 21 -year-old chef was punched in the mouth. He took out his chef's knife, which he was carrying in a bag with his apron and hat, and lashed out. He stabbed one of his tormentors, a 15-year-old, in the side and nearly killed him.

Now, what do one suppose the law says about situations like this? Would one assume that an innocent bus passenger, subjected to an unprovoked attack, has a right to defend himself? Well yes, he does. But if the law says actions taken in sefl-defence must be proportionate to the threat, then as you are being hassled, abused and bashed, you are supposed to be asking yourself: what might the law consider to be a reasonable and proportionate response in these circumstances? Perhaps you should ask your assailants to desist for a few minutes while you phone a lawyer for advice. Unfortunately,Shyan Ricky Hill lacked the presence of mind to do this. Frightened and angry, and no doubt with his fight-or-flight mechanism in overdrive, he "lost it" as many of us would in similar circumstances". (The Dominion Post 2007)

\section{Self Defence Under Nigerian Law}

The defence of self-defence is adequately provided for under Nigerian Law. In both the Nigerian Constitution and the two principal penal statutes in Nigeria - the Criminal Code and the Penal Code, elaborate and sufficient provisions are made for the defence. We shall begin with the Constitution.

\subsection{The 1999 Constitution of the Federal Republic of Nigeria (as Amended)}

Section 33 of the 1999 Constitution guarantees the fundamental right to life of every Nigerian Citizen. Subsection (2) (a) of the same section provides as follows:

A person shall not be regarded as having been deprived of his life in contravention of this section, if he dies as a result of the use, to such extent and in such circumstances as are permitted by the law, of such force as is reasonably necessary-

(a) for the defence of any person from unlawful violence or for the defence of property;

The substance of this provision is replicated in the penal statutes to the effect that a person is entitled to use such reasonable force as is necessary in defence of himself or any person from unlawful violence or for the defence 
of property. The corollary of this is that self-defence is constitutionally available to a person who is attacked by another.

\subsection{The Criminal Code and the Penal Code}

'Both the Criminal Code Act, and the Penal Code of Nigeria make elaborate provisions on the defence of self-defence. The provision spans sections 286-293 of the Criminal Code and sections 59-67 of the Penal Code Act. But for the purpose of this paper, we shall lay emphasis on sections 286 and 287 of the Criminal Code Act the full provisions of which are reproduced hereunder:

\section{Self-defence against unprovoked assault}

When a person is unlawfully assaulted, and has not provoked the assault, it is lawful for him to use such force to the assailant as is reasonably necessary to make effectual defence against the assault:

Provided that the force used is not intended, and is not such as is likely, to cause death or grievous harm.

If the nature of the assault is such as to cause reasonable apprehension of death or grievous harm, and the person using force by way of defence believes, on reasonable grounds, that he cannot otherwise preserve the person defended from death or grievous harm, it is lawful for him to use any such force to the assailant as is necessary for defence, even though such force may cause death or grievous harm.

\section{Self-defence against provoked assault}

When a person has unlawfully assaulted another or has provoked an assault from another, and that other assaults him with such violence as to cause reasonable apprehension of death or grievous harm, and to induce him to believe, on reasonable grounds, that it is necessary for his preservation from death or grievous harm, and to induce him to believe, on reasonable grounds, that it is necessary for his preservation from death or grievous harm to use force in self-defence, he is not criminally responsible for using any such force as is reasonably necessary for such preservation, although such force may cause death or grievous harm.

This protection does not extend to a case in which the person using force, which causes death or grievous harm, first began the assault with intent to kill or to do grievous harm to some person; nor to a case in which the person using force which causes death or grievous harm endeavoured to kill or to do grievous harm to some person before the necessity of so preserving himself arose; nor, in either case, unless, before such necessity arose, the person using such force declined further conflict, and quitted it or retreated from it as far as was practicable.

These are the salient provisions of the Criminal Code on self-defence. Other sections of the Act on the defence deal with aiding in self-defence and defence of property. With regard to aiding in self-defence, the law permits the person aiding to use a like degree of force for the purpose of defending that person as he would if he were the person under attack (section 288). However, with regard to defence of property, the law allows a person to use such reasonable force that would not do harm to the intruder. (Sections 289-293). This is not implicit in the constitutional provision. Other than that the term "private defence" is used in the Penal Code which is operative in Northern Nigeria rather than the term "self-defence" used in the Criminal Code which is operative in Southern Nigeria, the Provisions of the Penal Code on self-defence is substantially similar to that under the Criminal Code and would not be replicated here. It is then clear from the foregoing that the right to self-defence is guaranteed by extant Nigerian legislation. However, this article sets out to examine the yardstick applied in determining the proportion or excess thereof, of the defendant's retaliatory act in self-defence, in a criminal trial.

\section{Ingredients of Self-Defence}

The ingredients of self-defence refers to the facts and circumstances which a defendant must prove in order to succeed in a plea of self-defence. These facts and circumstances are distilled from statutory provisions on the subject and decisions of courts over the years. In Afosi v The State [(2013)13 NWLR (Pt. 1371) 329], the Supreme Court of Nigeria, while enumerating the ingredients of self-defence, held that the self-defence that will have any impact on a case to enure in favour of the defendant must be such that the act of the defendant was unavoidable. The court then listed the ingredients of self-defence as follows:

(a) The accused must be free from fault in bringing about the encounter;

(b) There must be present an impending peril to life or of great bodily harm either real or so apparent as to create honest belief of an existing necessity;

(c) There must be no safe or reasonable mode of escape by retreat, and

(d) There must have been a necessity for taking life. 
It is pertinent, for the purpose of this paper, to observe that the court in the case under reference said nothing about the proportionateness of the defendant's retaliatory act. In other cases, the courts have always highlighted this requirement that the defendant's retaliation must be proportionate to the threat posed by the act of the deceased.

Sheidu v. The State [(2014)15 NWLR (Pt. 1429)1]. In consonance with this position, the court held in Nkpuma v. The State [ (1993)9 NWLR (Pt. 317) 374] that where an unprovoked assault causes the defendant reasonable apprehension of death or grievous harm, he is entitled in law to use such force to defend himself as he believes, on reasonable grounds, to be necessary even though such force may cause death or grievous harm.

In all of these, the underlying condition for reliance on self-defence is that the defendant must be reasonably apprehensive of death at the time he uses any force as is necessary to preserve his life. The corollary of this is that the force used by the defendant need not be reasonable or proportionate. It is enough once there is in existence, on reasonable grounds as the defendant believes them to be, apprehension of death. This, in our opinon, obviates the necessity of determining whether or not the force used by the defendant is proportionate. This forms the subject of the next section of this paper.

\section{Measuring the "Propportionate-ness" of the Defendant's Retaliatory Act.}

One thing is clear in this area of our Criminal Law. By what criteria can one measure the retaliatory act of the defendant in order to determine whether it was commensurate or proportional to the danger posed by the deceased? There is yet no clear answer to this issue. And considering that the specific provision of section 286 of the Criminal Code of Nigeria (2004)

When a person is unlawfully assaulted, and has not provoked the assault, it is lawful for him to use such force to the assailant as is reasonably necessary to make effectual defence against the assault.

did not make any reference to the requirement of the defendant's act being proportionate, it is safe to state that those who hold the view, including the courts, that the force used by the defendant must be commensurate or proportionate to the deceased's threat, are merely reading into the law, what the legislature did not contemplate. What is relevant under the law is that once reasonable grounds exist for the defendant to be apprehensive of death; such a defendant is legally entitled to use any such force as is necessary to defend himself. In such a situation, the proportion of the force used becomes immaterial. The Supreme Court of Nigeria in the case of the Laoye v. The State [(1985)2 NWLR (Pt. 10) 832] supported this view. In his leading judgment in the case, Nnamani JSC made the point succinctly when he said:

Excessive force has been described as force which is more than a reasonable man would consider necessary. To my mind, the degree of force used is only relevant while one is considering the circumstances of the encounter so as to determine whether there were reasonable grounds for the prisoner's belief that his life is in danger. Once it is agreed that there were such grounds, the amount of force used by the prisoner to preserve his own life becomes immaterial.

With regard to the same issue of the amount of force used by the defendant in defending himself, Lord Morris of Boothy-Gest, in the case of Palmer v. R[(1971) AC 814] stated as follows:

All that is needed is a clear exposition in relation to the particular facts of the case of conception of necessary self-defence. If there has been no attack, then clearly there will have been no need for defence. If there had been attack so that defence is reasonably necessary, it will berecognized that a person defending himself cannot weigh to a nicety the exact measure of his necessary defensive action.

The foregoing discussion demonstrates the general principle of reasonable force; the law allows only reasonable force to be used in the circumstances and, what is reasonable is to be judged in the light of the circumstances as the defendant believed them to be (whether reasonably or not). In assessing whether a defendant had used only reasonable force, the court ought only to look at the particular facts and circumstances of the case which informed the defendant's belief. Thus, a person can use reasonable force if he is genuinely threatened with an impending injury. Such a person need not measure the proportion of the force to use. Once the apprehension is reasonably held, the amount of force used becomes immaterial.

\section{Conclusion}

As has been discussed in this paper, the defence of self-defence permits a defendant under the threat of death or serious bodily harm, to use reasonable and necessary force, to defend himself or property from unlawful violence. However, in applying the law, the courts read into the letter of the law, what has not been enacted by the legislature by holding that the retaliatory act of the defendant ought to be proportionate to the threat posed by the act of the deceased. This is against the backdrop of the statutory provisions and what obtains from other similar jurisdictions like Nigeria. The insistence of the courts on the proportionate-ness of the retaliatory act of the defendant is somewhat strange because the Nigerian Supreme Court had in Laoye v. The State held that once reasonable grounds exist for the defendant to be apprehensive of death, such a defendant is 
entitled to use such force as is necessary to defend himself and the amount of force he uses in so doing becomes immaterial.

But is it really possible to measure the amount of force ought to be used by the defendant? It is the conclusion of this paper that there is no yardstick to measure the appropriate amount of force such a defendant ought to use. In the cases of Basil Parisiris, Adenike and Shyan Ricky Hill, how could they have in their respective circumstances measured the appropriate amount of force with which to defend themselves? It is impossible to do so. It is our opinion and we agree with the Supreme Court of Nigeria in Laoye v. The State, that what is relevant in each case is that there is in existence, a reasonable apprehension of death or grievous bodily harm as the defendant believed it to be. It is immaterial to consider the amount of force he used. This is because such a defendant, in such a situation, cannot weigh to a nicety, the exact amount or measure of his necessary defensive action. Besides, there is nothing in the statute requiring that the defendant's retaliatory act be proportionate or commensurate with the threat posed by the assailant. It is in view of the foregoing that we recommend that the courts should apply the law as enacted by the legislature and not read into it what the legislature has not enacted. This is to stem miscarriage of justice by foisting on a defendant, the burden the legislature has not created.

[1]. Afosi v. State [2013]13 NWLR (Pt. 1371) 329.

\section{References}

[2]. Ashworth, A. (1991), Principles of Criminal Law 114, (Cited in Black's Law Dictionary, P. 1390).

[3]. Dachen, Isaac (2015) "Super Woman: Lady Stabs Robber to Death inSelf-Defence" available at http://pulse.ng/gist/superwomanladystabs-robber-to-death-in-self-defence-id4030128.html (accessed on 11/2/2016).

[4]. Ewulum, B E \&Agwuncha, I E, (2013) "An Analysis of the Defence of Self-Defence under Nigeria Law," The Premier Bar Journal, Vol. 1, N0. 1, 2013, P. 161.

[5]. Frier, B \& McGinn, T; (2004), A Casebook on Roman Family Law (New York: Oxford Unviversity Press) P. 67

[6]. Garner, B A, (2004) Black's Law Dictionary (St. Paul, MN: West Publication Co.) P. 1390.

[7]. Hobbes, T (1909) Leviathan (Oxford: Clarendon Publishers) P. 132

[8]. Jeremiah v. State (2012)14 NWLR (Pt. 1320)248

[9]. Laoye v. State [1985]2 NWLR (Pt. 10)832

[10]. Nkpuma v. State [1993]9 NWLR (Pt. 317)374.

[11]. Palmer v. R [1971] AC 814

[12]. Saunders, J B: (1970) Words and Phrases Legally Defined, Vol. V P. 39 (cited in Yadav)

[13]. Sheidu v. State [2014]15 NWLR (Pt. 1429)1

[14]. The Constitution of the Federal Republic of Nigeria (1999)

[15]. The Criminal, Code, Cap. C38, Laws of the Federation of Nigeria, 2004

[16]. The Dominion Post (2007): "The Law has lost its sense of proportionon self-Defence" available at http://www.stuff.co.nz/blogs/opinon/32468/1-The-law-has-lost-its-sense-of-proportion-on-self-defence-i (accessed on 8/2/2016)

[17]. The Penal Code, Cap Laws of Northern Region of Nigeria, 1959.

[18]. Universal Declaration of Human Rights (1948), Article 12.

[19]. Walker, D M, (1980) The Oxford Companion of Law (Oxford ) P. 1128

[20]. Warder, R (2014): “10 shocking Controversial Self-Defence Cases," available at http://listverse:com/2014/02/16/10-schockingcontroversial-self-defence-cases/ (accessed on 11/2/2016)

[21]. Yadav, RD (1993), Law of Crime and Self-Defence, (New Delhi: Mittal Publications) P. 13. 